Uniwersytet im. Adama Mickiewicza, Poznań

\title{
Wybrane problemy z właściwą wykładnią umów prawa autorskiego
}

$W_{\text {znaczenie i doniosłość prawną, ale także ekonomiczną i społeczną }}^{\text {ostatnim okresie w obrocie prawnym dostrzega się coraz wieksze }}$ umów autorskich. Z uwagi na skalę tego zjawiska, nie dziwi rosnący problem właściwej wykładni takich kontraktów. Poniżej podjęto próbę zaprezentowania tylko niektórych istotnych problemów pojawiających się w procesie prawidłowej interpretacji takich oświadczeń woli podmiotów prawa. Wydaje się, że w świetle doświadczeń wynikających z praktyki, opisywane poniżej aspekty tego zjawiska zasługują na szczególną uwagę. Konieczne zatem okazało się dokonanie przeglądu najważniejszych poglądów doktryny i judykatury w tym zakresie.

Na wstępie należy przypomnieć, że w świetle ustawy z dnia 4 lutego 1994 r. o prawie autorskim i prawach pokrewnych ${ }^{1}$ wyraźnie rozróżnia się umowy przenoszące prawa majątkowe autorskie oraz umowy licencyjne. Jest to o tyle istotne, że jak podkreśla się w doktrynie ,w istocie rzeczy [...] o przeniesieniu praw powinno się mówić tylko wtedy, gdy prawa autorskie do utworu przenosimy w całości na inną osobę albo co najmniej w takiej części, która zarówno prawnie, jak i gospodarczo sama w sobie posiada pewne immanentne i samodzielnie znaczenie gospodarcze i wartość. W przypadku zbytniego «rozczłonkowania» prawa autorskiego na elementy pozbawione powyższej cechy powinno się mówić tylko o licencji, a nie o przejściu prawa [...]. Przepis ten [tj. art. 65 ustawy - przyp. J.S.] przewiduje, że w braku wyraźnego postanowienia o przeniesieniu prawa uważa się, że twórca udzielił licencji. Postanowienie to w świetle powyższych wyjaśnień pozwala także na jego szerszą interpretację. Zmierza ona do poglądu, że z licencją mamy do czynienia także wtedy, gdy strony wyraźnie przewidziały przejście prawa, jednakże prawo to ukształtowały tak wąsko, że nie ma ono samodzielnego znaczenia i odrębnej wartości.

1 T.j. Dz. U. 2006, Nr 90, poz. 631 z późn. zm. dalej zwana ustawą. 
I w takim przypadku zatem określilibyśmy umowę jako licencję, mimo że strony nazwały ją błędnie umową o przejście praw autorskich"”. Podobne stanowisko prezentuje judykatura. I tak w wyroku Sądu Apelacyjnego w Warszawie z dnia 9 listopada 2006 r. ${ }^{3}$ podkreślono, że charakter umowy wynika z jej treści, niemniej jednak należy także mieć na uwadze art. 65 ustawy o prawie autorskim i prawach pokrewnych nakazujący tłumaczyć wszelkie wątpliwości na korzyść twórcy i w takim wypadku przyjąć licencyjny charakter umowy.

Zgodnie z art. 41 ust. 2 ustawy umowa o przeniesienie autorskich praw majątkowych lub umowa o korzystanie $\mathrm{z}$ utworu, [...], obejmuje pola eksploatacji wyraźnie w niej wymienione. Na tle takiego stanu prawnego mogą pojawić się wątpliwości, jak należy wykładać ten przepis, zwłaszcza w sytuacji, gdy umowa została w tym zakresie napisana nieprecyzyjnie (a tak dzieje się często). Zdaniem doktryny ,pominięcie bądź wskazanie w umowie określonych pól eksploatacyjnych będzie miało decydujące znaczenie dla wykładni umowy, dla wyznaczenia jej treści. Ewentualne wątpliwości powstające na tym tle mogą być związane $\mathrm{z}$ interpretacja przesłanki «wyraźnie wymienione». Zostanie ona niewątpliwie spełniona wówczas, gdy strony enumeratywnie i precyzyjnie określą pola eksploatacji, posługując się przy tym «nazewnictwem» przyjętym we wspomnianym art. 50"4.

Takie wątpliwości pojawiają się zwłaszcza w przypadkach, gdy w treści umowy zostanie użyte wspólne określenie dla kilku pól eksploatacji, bez sprecyzowania np. czy chodzi o nadanie bezprzewodowe przez stację naziemną, kablową czy za pośrednictwem satelity albo użyte zostanie sformułowanie nieznane art. 50 (np. emitowanie) $)^{5}$.

Natomiast w kwestii uznania, jakie są konsekwencje braku dochowania tej przesłanki tj. określenia ,pól eksploatacji wyraźnie wymienionych w umowie", opinie nauki prawa są podzielone. Zdaniem M. Kępińskiego niedokładne określenie pól eksploatacyjnych nie powinno prowadzić do upadku umowy, ,[...] chyba że byłaby ona tak sformułowana, że nie pod-

2 M. Kępiński, Umowy prawa autorskiego, w: System Prawa Prywatnego, t. 13: Prawo autorskie, red. J. Barta, Warszawa 2003, s. 429.

3 Wyrok Sądu Apelacyjnego w Warszawie z dnia 9 listopada 2006 r. (sygn. akt I ACa 487/2006, opublik. w „LexPolonica” nr 420110, „,Rzeczpospolita” 2006/265/C3).

4 Tak J. Barta, R. Markiewicz, Prawo autorskie i prawa pokrewne. Komentarz, Kraków 2005, s. 390.

5 Patrz szerzej. J. Barta, R. Markiewicz, op. cit., s. 390. 
dawałaby się rozsądnej wykładni [...]. Można uważać, że sankcją nieścisłego określenia tych pól jest skuteczność umowy tylko w zakresie pól wyraźnie wymienionych, a ponadto umowa podlega ogólnym regułom wykładni" ". Zdaniem z kolei J. Barty i R. Markiewicza, taki pogląd będzie uzasadniony tylko „w tym zakresie, w jakim taka interpretacja rekonstruuje niewątpliwą wolę twórcy"7. Pogląd ten zdaje się znajdować potwierdzenie w wyroku Sądu Najwyższego z dnia 5 marca 2002 r. ${ }^{8}$ Otóż stwierdza się tu, iż „przeniesienie praw musi być w umowie dokładnie określone, tj. jakich pól eksploatacji przeniesienie dotyczy, albowiem w art. 41 ust. 2 wyrażona została istotna dla praktyki obrotu prawami autorskimi norma, według której treść umowy mającej za przedmiot prawa autorskie [...] odnosi się tylko do pól eksploatacyjnych, które zostały w niej wyraźnie wymienione. Wskazanie bądź pominięcie danego pola eksploatacji ma decydujące znaczenie dla wyznaczenia treści i sposobu interpretacji umowy licencyjnej [...]"9.

Przypomnieć także trzeba, że w ramach tzw. pierwotnych umów autorskich, czyli łączących twórców z podmiotami korzystającymi z dzieł autorskich, obowiązujące prawo autorskie skierowane jest na ochronę słabszej strony tego stosunku prawnego, czyli twórcy. Zdaniem niekwestionowanego poglądu doktryny ,pierwotne stosunki umowne, powstające bezpośrednio pomiędzy twórcą a osobami korzystającymi z utworów, charakteryzują się ogólnym założeniem o potrzebie ochrony słabszego partnera umowy, którym jest twórca. Ta ochrona [...] sprowadza się do przeciwdziałania nabyciu przez korzystającego «nadmiaru» praw autorskich w stosunku do celu, któremu umowa ma służyć [...] wreszcie przepisy zabezpieczają także prawa twórcy do otrzymania wynagrodzenia adekwatnego do korzyści uzyskiwanych przez nabywcę praw. Regułą wykładni norm rozdziału 5 [ustawy - przyp. J.S.] powinna być zasada, że trzeba je interpretować na korzyść autora [podkr. J.S.], jeżeli autor w nich występuje"10.

6 Tak M. Kępiński, op. cit., s. 433, 434.

7 J. Barta, R. Markiewicz, op. cit., s. 392.

8 Zob. wyrok Sądu Najwyższego z dnia 5 marca 2002 r. - Izba Karna II KKN 341/99, opublik. w OSNKW 2002, nr 9-10, poz. 82, „Biuletyn Sądu Najwyższego”, nr 9, s. 19; wyrok cytowany także w: J. Barta, R. Markiewicz, op. cit., 390.

9 Por. wyrok SN z dnia 27.11.1962 r., sygn. akt II CR 15/63, OSN 1964, z. 11, poz. 228 oraz niepubl. wyrok SN z dnia 16.05.1964 r. przywołany w J. Barta, R. Markiewicz, op. cit., 390.

10 M. Kępiński, op. cit., s. 426 i 428, podobnie J. Barta, R. Markiewicz, op. cit., s. $390-391$. 
Mając powyższe na uwadze, przychylić należy się także do stanowiska przedstawicieli doktryny, że „w tym zakresie [tj. wykładni umów - przyp. J.S.] należy w każdym przypadku sięgnąć do ogólnych kryteriów wykładni przewidzianych w art. 65 k.c. Przepis ten nakazuje raczej badać zgodny zamiar stron i cel umowy niż opierać się na jej dosłownym brzmieniu. Celem umowy są typowe skutki gospodarcze lub społeczne, łączące się z zawarciem określonej umowy (element obiektywny), zamiarem stron są natomiast indywidualne skutki, które strony chciały zgodnie osiaggnąć, idąc ponad ogólniej ujęty cel umowy. [...] Nie ulega wątpliwości, że umowy autorskie podlegają także ogólnym regułom wykładni nakazującym w pierwszym rzędzie zwracać uwagę na warstwę słowną umowy i jej znaczenia. Zgodny zamiar stron i cel umowy nie moga przekreślać tego, co strony zapisały w tekście umowy. Lecz przeciwnie powinny zmierzać do pełnego urzeczywistnienia tych założeń, które znalazły wyraz w treści umowy. W pierwszym rzędzie należy zatem interpretować warstwę językową umowy i starać się ustalić jej sens”,11. [...] „Dalszą zasadą wykładni umów jest reguła, że należy brać pod uwagę okoliczności w jakich oświadczenie zostało złożone [...]. Na wykładnię umowy rzutują także zasady współżycia społecznego"12. Powyższe stanowisko znajduje odzwierciedlenie także w poglądach judykatury. I tak w wyroku Sądu Najwyższego z dnia 23. 09.2004 r. ${ }^{13}$ sformułowano następującą tezę ,zawarte $\mathrm{w}$ art. 65 k.c. zasady tłumaczenia oświadczeń woli wymagają przede wszystkim odniesienia się do całego złożonego oświadczenia woli, a nie jedynie do jego wybranego dowolnie fragmentu. Wymagają także zbadania okoliczności $w$ jakich oświadczenie zostało złożone i jego celu. [...] Zgodnie z art. $41 \S 2 \mathrm{w}$ zw. z art. 50 oraz art. 67 § 1 ustawy z dnia 4 lutego 1994 r. o prawie autorskim i prawach pokrewnych [...] zarówno umowa przeniesienia majątkowych praw autorskich, jak i umowa licencyjna, obejmują pola eksploatacji wyraźnie w nich określone, co oznacza, że określenie pól eksploatacji, w rozumieniu art. 50 Prawa autorskiego, stanowi essentialia negotii takiej umowy".

Należy także zauważyć, że w doktrynie trafnie zauważa się, że wyliczenie pól eksploatacji z art. 50 ustawy jest jedynie przykładowe, stąd też strony mogą ustalić i określić w umowie inny sposób korzystania z dzieła, bo

11 M. Kępiński, op. cit., s. 439-440.

12 Ibidem, s. 440.

13 Wyrok Sądu Najwyższego z dnia 23.09.2004 r. (sygn. Akt III CK 400/03, opublik. LEX nr 174201. 
tym w istocie jest tzw. pole eksploatacji1 ${ }^{14}$. Przypomnijmy, iż zgodnie z przytoczonym przepisem odrębne pola eksploatacji stanowią w szczególności:

1) w zakresie utrwalania i zwielokrotniania utworu - wytwarzanie określoną techniką egzemplarzy utworu, w tym techniką drukarską, reprograficzna, zapisu magnetycznego oraz techniką cyfrową;

2) w zakresie obrotu oryginałem albo egzemplarzami, na których utwór utrwalono - wprowadzanie do obrotu, użyczenie lub najem oryginału albo egzemplarzy;

3) w zakresie rozpowszechniania utworu w sposób inny niż określony w pkt 2 - publiczne wykonanie, wystawienie, wyświetlenie, odtworzenie oraz nadawanie i reemitowanie, a także publiczne udostępnianie utworu w taki sposób, aby każdy mógł mieć do niego dostęp w miejscu i w czasie przez siebie wybranym.

W praktyce, zwłaszcza z uwagi na postęp technologiczny, wiele problemów rodzi właściwa wykładnia pojęć „nadawanie” i „reemitowanie”. Stąd wyjaśnić tu trzeba, że zgodnie z definicją ustawową zamieszczoną w art. 6 ust. 1 pkt 4 ustawy nadawaniem utworu jest jego rozpowszechnianie drogą emisji radiowej lub telewizyjnej, prowadzonej w sposób bezprzewodowy (naziemny lub satelitarny) lub w sposób przewodowy. Wprawdzie w art. 50 pkt 3 ustawodawca posługuje się określeniem nadawanie (bez wyszczególniania na nadawanie naziemne przewodowe, bezprzewodowe, nadawanie za pośrednictwem satelity) to nie ma w doktrynie wątpliwości, że każdy z wyżej wymienionych sposobów stanowi odrębne pole eksploatacji ${ }^{15}$. Oczywiście w każdym z tych przypadków przekaz musi mieć charakter publiczny co oznacza, iż „w miejscu przeznaczenia sygnały mogą być odebrane przez dowolną liczbę odbiorców. Publiczny charakter nadania nie jest natomiast uzależniony od tego, czy sygnały mogą być odbierane bez użycia dodatkowych urządzeń technicznych, czy też odbiorca powinien posłużyć się specjalną anteną lub dekoderem ${ }^{16}$. Nie ma zatem wątpliwości, iż „nadanie za pośrednictwem satelity, czyli tzw. emisji satelitarnej stanowi przedmiot odrębnego wyłącznego uprawnienia [...]"17. Warto tu przywołać wyrok Sądu Najwyższego z 10.12.2004 r. ${ }^{18}$,

14 Szerzej M. Kępiński, op. cit., s. 432.

15 Patrz szerzej E. Traple, Komentarz do art. 50, w: J. Barta, R. Markiewicz, op. cit., s. 437.

16 Ibidem, s. 438.

17 Ibidem, s. 440.

18 Wyrok Sądu Najwyższego z 10.12.2004 r., sygn. akt III CK 99/04, opublik. LEX nr 183749, teza 2. 
w którym wyrażono pogląd, iż w przepisach ustawy w pierwotnym brzmieniu istniało rozróżnienie pojęć „,nadanie” oraz „,równoczesne i integralne nadanie". I tak w art. 50, określającym przykładowo pola eksploatacji, wymienia się w pkt 10 ,nadanie za pomocą wizji lub fonii przewodowej lub bezprzewodowej przez stację naziemną”, w pkt 11 „,nadanie za pośrednictwem satelity”, a w pkt 12 ,równoczesne i integralne nadanie utworu nadawanego przez inną organizację radiową lub telewizyjną". Są to zatem różne pola eksploatacji.

$\mathrm{Z}$ kolei pojęcie reemitowania utworu ustawodawca zdefiniował w art. 6 ust. 1 pkt 5 ustawy. Zgodnie z tym przepisem, pod tym pojęciem należy rozumieć jego rozpowszechnianie przez inny podmiot niż pierwotnie nadający, drogą przejmowania w całości i bez zmian programu organizacji radiowej lub telewizyjnej oraz równoczesnego i integralnego przekazywania tego programu do powszechnego odbioru. Wreszcie, w myśl art. 6 pkt 9 publicznym odtworzeniem utworu jest jego udostępnienie bądź przy pomocy nośników dźwięku, obrazu lub dźwięku i obrazu, na których utwór został zapisany, bądź przy pomocy urządzeń służących do odbioru programu radiowego lub telewizyjnego, w którym utwór jest nadawany.

Raz jeszcze wypada powtórzyć, iż w świetle powyższych wywodów nie ma najmniejszych wątpliwości, iż nadawanie i reemitowanie, ale także publiczne odtworzenie będą uchodzić za odrębne pola eksploatacji. Potwierdzenie takiego poglądu znaleźć można w tezie zawartej w uzasadnieniu wyroku Sądu Apelacyjnego w Warszawie z dnia 8.02.2005 r. ${ }^{19}$, zgodnie z którym „reemisja programów radiowych i telewizyjnych w sieci kablowej jest odrębnym polem eksploatacji praw autorskich".

W pełni należy także zaaprobować pogląd, iż „treść umowy nie musi odnosić się do całego zakresu pola eksploatacji wymienionego w jednym z punktów art. 50. Ograniczenia mogą mieć różny charakter, np. terytorialny, czasowy, przedmiotowy (odnoszący się choćby tylko do wybranych sposobów publicznego odtwarzania czy zwielokrotniania)"20.

Dodatkową kwestią wymagająca podkreślenia, jest okoliczność, iż w kreowaniu odrębnych pól eksploatacji należy brać pod uwagę także kryterium nowego kręgu odbiorców. „Kryterium to znajduje wyraźne zastosowanie w zakresie praw wydawniczych, w których jako oddzielne

19 Wyrok Sądu Apelacyjnego w Warszawie z dnia 8.02.2005 r., sygn. akt VI ACa 578/04, opubl. Apel.-Warszawa 2005/4/38 w Warszawie.

20 Tak J. Barta, R. Markiewicz, op. cit., s. 394. 
sposoby eksploatacji traktuje się wydania w formie luksusowej, popularnej, kieszonkowej, bogato ilustrowane i bez ilustracji. [...] Dotarcie do nowej publiczności było jedną z podstaw wyodrębnienia jako oddzielnego pola eksploatacji przekazu satelitarnego i kablowego. W niektórych przypadkach za decydujący dla rozgraniczenia pól eksploatacji uznaje się fakt, że rozpowszechnianie dokonuje inny podmiot niż ten, kto to rozpowszechnianie rozpoczął, jak to jest w przypadku reemisji. Inne kryterium wyodrębniania stanowi także terytorialny zasięg użytku" 21.

W tym kontekście warto również przywołać orzeczenie Sądu Apelacyjnego w Warszawie z 17 stycznia 1992 r. ${ }^{22}$, w którym stwierdza się, że „rozpowszechnianie filmów na kasetach wideo odbiega w zasadniczy sposób od rozpowszechniania na poprzednio znanych polach publikacji tj. w kinach i telewizji, przede wszystkim z punktu widzenia komercyjnego, bowiem utwór powielony jest w nieporównywalnie większej ilości kopii i odtwarzany częściej [...]. Nie można więc przyjąć, że autor przeniósł prawa do rozpowszechniania utworu na wideokasetach poprzez ogólne postanowienie umowne, iż przenosi prawo do rozpowszechniania utworu zgodnie z jego przeznaczeniem"23.

Podzielić należy także pogląd zaprezentowany w piśmie Ministerstwa Kultury i Sztuki z dnia 4.10.1996 r. ${ }^{24}$ odnośnie do art. 41 ust. 2 ustawy, iż $\mathrm{w}$ przypadku nieokreślenia $\mathrm{w}$ umowie wynagrodzenia za takie odrębne pole eksploatacji jego wysokość określić należy z uwzględnieniem zakresu udzielonego prawa oraz korzyści wynikających z korzystania z utworu.

Pamiętać należy, że zgodnie z treścią art. 43 ust. 1, jeżeli z umowy nie wynika, że przeniesienie autorskich praw majątkowych lub udzielenie licencji nastąpiło nieodpłatnie, twórcy przysługuje prawo do wynagrodzenia. $Z$ kolei w ust. 2 tego przepisu stanowi się, że jeżeli w umowie nie określono wysokości wynagrodzenia autorskiego, wysokość wynagrodzenia określa się z uwzględnieniem zakresu udzielonego prawa oraz korzyści wynikających z korzystania z utworu. Podzielić należy także stanowisko doktryny, iż ,przepis ten [...] wprowadza [...] domniemanie wzruszalne, że o ile umowa nie stanowi inaczej, to twórca ma prawo do

${ }^{21}$ E. Traple, op. cit., s. 419-420.

22 Orzeczenie Sądu Apelacyjnego w Warszawie z 17 stycznia 1992 r. sygn. akt I ACr 296/91, niepublikowane (zachowujące nadal aktualność).

${ }^{23}$ Tak wyrok cytowany w J. Barta, R. Markiewicz, op. cit., s. 391.

${ }^{24}$ Pismo Ministerstwa Kultury i Sztuki z dnia 4.10.1996 r. (DPA.024/346/96, opublik. LEX nr 2967). 
wynagrodzenia. Reguła ta ma zastosowanie nawet wówczas, gdy strony nie postanowiły nic w sprawie wynagrodzenia ${ }^{25}$. Na aprobatę zasługuje również teza, iż ,wobec przyjętego w ustawie wymogu formy pisemnej ad solemnitatem $\mathrm{w}$ odniesieniu do umów przenoszących prawa oraz umów licencyjnych odmówienie twórcy prawa do wynagrodzenia przy tego rodzaju umowach nie może nastapić, gdy ustalenia w sprawie braku odpłatności nie znalazły wyrazu w tekście umowy, a jedynie w ustnych ustaleniach",26.

Niezwykle istotne znaczenie ma również prawidłowa wykładnia art. 45 ustawy, który stanowi, iż jeżeli umowa nie stanowi inaczej, twórcy przysługuje odrębne wynagrodzenie za korzystanie z utworu na każdym odrębnym polu eksploatacji. Szczególnie ważne jest stanowisko prezentowane w doktrynie, iż ,art. 45 może znaleźć zastosowanie, gdy strony przewidują określony sposób korzystania z dzieła [...] a następnie rozszerzają umowę na nowe użytki i nie wprowadzają za taki użytek dodatkowego wynagrodzenia. W takim przypadku twórca będzie mógł domagać się dodatkowego wynagrodzenia na użytek z utworu na nowym polu eksploatacji. [...] Umowa z reguły będzie wynagrodzenie określać za wszelkie pola nią objęte. Strony nie muszą określać odrębnego wynagrodzenia za każde pole eksploatacji. Jeżeli jednak wynagrodzenie nie zostało przewidziane za jakieś odrębne umową pole, to korzystający z utworu musi to wynagrodzeni zapłacić dodatkowo" 27.

Warto odnotować pogląd, iż „treść prawa do wynagrodzenia polega na możności żądania zapłaty odpowiedniej kwoty za każde korzystanie z utworu w zakresie, w jakim jest on objęty monopolem twórcy, i wyczerpuje się w postaci roszczenia do zindywidualizowanego podmiotu, które powstaje z chwilą skorzystania z cudzego utworu. [...] Podstawą domagania się wynagrodzenia od podmiotu zobowiązanego do świadczenia może być bądź przepis ustawy (np. w zakresie tzw. użytku publicznego), bądź umowny stosunek zobowiązaniowy albo też samo korzystanie z cudzego utworu objętego ochroną prawa autorskiego" ${ }^{28}$. Ponadto podzielić należy w pełni twierdzenie, że z powyższą zasadą związana jest reguła ,[...] odrębności wynagrodzenia za stworzenie i dostarczenie dzieła oraz za prze-

25 M. Kępiński, op. cit., s. 484.

26 Tak J. Barta, R. Markiewicz, op. cit., s. 400.

27 M. Kępiński, op. cit., s. 485.

28 Tak M. Puźniak-Niedzielska, Zasada swobody umów a prawo twórcy do wynagrodzenia, „Rzeczpospolita” 1996, nr 10, s. C3. 
niesienie praw autorskich. Na tej podstawie przyjmuje się w praktyce, że jeżeli z umowy nie wynika, iż określone w niej wynagrodzenie jest wynagrodzeniem nie tylko za sporządzenie i dostarczenie dzieła, ale i za przyznanie drugiej stronie określonych uprawnień objętych treścią prawa autorskiego - wówczas za przeniesienie autorskich praw majątkowych lub upoważnienie do korzystania z utworu autorowi przysługuje odrębne wynagrodzenie" 29 . W tym nurcie pozostaje teza, iż „skutkiem istnienia przedmiotowej odrębności (odrębność wynagrodzenia należnego twórcy za stworzenie i dostarczenie dzieła) utworu od wynagrodzenia za przeniesienie autorskich praw majątkowych (udzielenie licencji) do tego utworu, jest konieczność określenia w umowie, iż wynagrodzenie należne twórcy obejmuje również honorarium za przeniesienie autorskich praw majątkowych (udzielenie licencji) bądź odrębne określenie wynagrodzenia za stworzenie i dostarczenie dzieła oraz wynagrodzenia za określonej treści rozporządzenie autorskimi prawami majątkowymi. Przyjmuje się, że brak tej treści postanowień w umowie oznacza, że określone w niej wynagrodzenie (za stworzenie i dostarczenie dzieła) nie obejmuje wynagrodzenia autorskiego za przeniesienie autorskich praw majątkowych (udzielenie licencji) i tym samym twórcy służy względem nabywcy (licencjobiorcy) roszczenie o jego zapłatę" 30 .

Okolicznością, która jeszcze bardziej utrudnia wykładnię takich umów jest to, że ustawa nie zawiera definicji utworu audiowizualnego. W doktrynie panuje jednak w pełni akceptowane stanowisko, że w tej kategorii zmieszczą się zarówno dzieła filmowe, jak i dzieła stworzone inną techniką np. wideo zawierające utrwalone obraz i dźwięk. A skoro tak, to przypomnieć tu trzeba treść art. 69, zgodnie z którym współtwórcami utworu audiowizualnego są osoby, które wniosły wkład twórczy w jego powstanie, a w szczególności: reżyser, operator obrazu, twórca adaptacji utworu literackiego, twórca stworzonych dla utworu audiowizualnego utworów muzycznych lub słowno-muzycznych oraz twórca scenariusza.

Warto podkreślić, że zgodnie z art. 43 ust. 2 ustawy, ,jeżeli w umowie nie określono wysokości wynagrodzenia autorskiego, wysokość wynagrodzenia określa się z uwzględnieniem zakresu udzielonego prawa oraz korzyści wynikających z korzystania z utworu”. Z całą mocą należy pod-

29 J. Barta, R. Markiewicz, op. cit., s. 404-405.

30 A. Gosiąrowski, Przejście autorskich praw majatkowych, „Radca Prawny” 2008, nr 3, s. 54-65. 
kreślić, iż tylko te dwa kryteria powinny być brane przy uwzględnianiu wysokości wynagrodzenia. Takie stanowisko znalazło potwierdzenie w wyroku Sądu Najwyższego z dnia 25 marca 2004 r. ${ }^{31}$ Stąd też przychylić należy się do zdania doktryny, iż „oceniając zakres udzielonego prawa, trzeba brać pod uwagę nie tylko ,ilość pól eksploatacyjnych objętych umową, ale również aspekt terytorialny i czasowy danej umowy. Z kolei druga przesłanka odwołuje się do korzyści wynikających z eksploatacji utworu; chodzi tu o korzyści o charakterze ekonomicznym. $Z$ reguły jednak są one trudne do ustalenia, m.in. dlatego nie należy brać pod uwagę korzyści już osiaggniętych, lecz trzeba uwzględniać również korzyści przyszłe i hipotetyczne"32.

Na zakończenie warto przywołać tezę zamieszczoną w wyroku Sądu Najwyższego z dnia 29.11.2006 r. ${ }^{33}$ Zdaniem SN wynagrodzenie stosowne w rozumieniu art. 79 ust. 1 ustawy z 1994 r. o prawie autorskim i prawach pokrewnych, to takie wynagrodzenie, jakie otrzymywałby autor, gdyby osoba, która naruszyła jego prawa majątkowe, zawarła z nim umowę o korzystanie z utworu w zakresie dokonanego naruszenia. Jeżeli organizacja zbiorowego zarządzania nie dysponuje zatwierdzoną tabelą wynagrodzeń i strony nie określą wysokości wynagrodzenia w drodze porozumienia, wynagrodzenie winno być ustalone przez sąd, zgodnie ze wskazówkami zawartymi w art. 110 ustawy. Dotyczy to także stosownego wynagrodzenia w rozumieniu art. 79 ust. 1 ustawy, w sytuacji, w której podstawę jego ustalenia stanowi niezatwierdzona tabela wynagrodzeń, kwestionowana z powodu niedochowania przy jej ustalaniu wskazówek przewidzianych w art. 110 ustawy".

Jak z powyższego wynika, prawidłowa wykładnia umów autorskich nastręczać może wiele trudności. A przecież przedstawiono tu tylko wybrane problemy spotykane w obrocie prawnym. Najczęściej wynikają one z zaniedbań stron takich kontraktów. Trzeba jednak przyznać, że problemy są skutkiem błyskawicznego postępu technicznego, za którym ustawodawca nie zawsze nadąża.

31 Wyrok Sądu Najwyższego z dnia 25 marca 2004 r., sygn. akt II CK 90/2003, opublik. „Biuletyn Sądu Najwyższego” 2004, nr 7.

32 J. Barta, R. Markiewicz, op. cit., s. 401.

33 Tak wyrok Sądu Najwyższego z dnia 29.11.2006 r.sygn. akt II CSK 245/06, opublik. LEX nr 233063. 


\section{Summary}

Recently, the increasing importance and the legal, as well as business and social, significance of copyright agreements has been noted in legal dealings. Given the growing range of such agreements one should not be surprised about the increasing problem of their correct interpretation. This paper attempts to present only some of the significant problems encountered in the process of the correct interpretation of such declarations of intent made by legal entities. In the light of practical experience it appears that the issues that are discussed in the paper should be considered with particular attention. The problems that usually arise are the consequence of negligence of the parties to such agreements. It should also be admitted, however, that another reason for problems may be rapid technical progress that legislation cannot always keep up with. Therefore, it has been necessary to review the most important opinions expressed in the doctrine and judicial decisions in this respect. 
